\title{
Implication of Prolonged Administration of Tramadol on Reproductive Performance of Male Wistar Rats
}

\author{
A. O. Oladejo ${ }^{1 *}$, O. O. Ajala ${ }^{2}$, A. A. Bakre ${ }^{1}$, A. A. Oloye ${ }^{3}$, O. S. Ajani ${ }^{2}$ \\ ${ }^{1}$ Department of Animal Health Technology, Oyo State College of Agriculture and Tech, Igboora, Nigeria \\ ${ }^{2}$ Department of Veterinary Surgery and Reproduction, University of Ibadan Nigeria \\ ${ }^{3}$ Department of Veterinary Public Health and Reproduction, Federal University of Agriculture, Abeokuta, Nigeria
}

DOI: $10.36347 /$ sjavs.2020.v07i09.001

| Received: 15.06.2019 | Accepted: 10.07.2019 | Published: 04.09.2020

*Corresponding author: Oladejo Ayodele Olaolu

Abstract

Original Research Article

Tramadol is a centrally active synthetic opioid analgesic that is used extensively in abolishing pain in animals. The effect of prolonged administration of tramadol on some reproductive parameters of wistar strain albino rats was studied. Fifteen sexually matured male albino rats weighing between $150-200 \mathrm{~g}$ were divided into three groups (A, B and $\mathrm{C}$ ) of five rats in each. Group A (control) was given distilled water while the experimental groups B and C were treated orally with $50 \mathrm{mg} / \mathrm{kg}$ and $100 \mathrm{mg} / \mathrm{kg}$ of tramadol respectively for 28 days. The hormone profile of groups B and $\mathrm{C}$ male rats showed a significant decrease $(\mathrm{p}<0.05)$ in $\mathrm{LH}, \mathrm{FSH}$ and testosterone value and a significant increase $(\mathrm{p}<0.05)$ in prolactin which was dose dependent compared to the control. These findings probably indicate that prolonged oral tramadol administration has a deleterious effect on sex hormone production and can precipitate infertility in the male wistar rats; hence its use must be with caution in animals meant for breeding purpose.

Keywords: Wistar rat, hormone, tramadol.

Copyright @ 2020: This is an open-access article distributed under the terms of the Creative Commons Attribution license which permits unrestricted use, distribution, and reproduction in any medium for non-commercial use (NonCommercial, or CC-BY-NC) provided the original author and source are credited.

\section{INTRODUCTION}

Tramadol was first used in therapeutic analgesia in Germany in 1977. Since this time its use has become more widespread and it has been registered and marketed in most countries by 2005 [1]. Tramadol is a centrally acting analgesic, and is increasingly used for analgesia in animal. It has only recently gained significant attention as an analgesic in animal despite its having been used in humans in Germany since 1977 and in North America since the mid 1980's [2]. The $\mathrm{LD}_{50}$ in mice and rats has been determined to be 350 $\mathrm{mg} / \mathrm{kg}$ and $228 \mathrm{mg} / \mathrm{kg}$, respectively, following an oral dose of tramadol [3]. In addition, an $\mathrm{LD}_{50}$ of $200 \mathrm{mg} / \mathrm{kg}$ and $286 \mathrm{mg} / \mathrm{kg}$ has been reported in mice and rats, respectively, following a subcutaneous dose [4]. Tramadol has a linear pharmacokinetic profile within the therapeutic dosage range [5]. Tramadol is rapidly and almost completely absorbed after oral administration following a mean absorption delay of approximately thirty minutes. The absorption half-life $\left(\mathrm{t}^{1 / 2}\right)$ is $23 \mathrm{hr} 11$ minutes [6]. Tramadol and its metabolites are excreted mainly by the kidneys with a cumulative renal excretion (tramadol and metabolites) of approximately $95 \%$ in animal and approximately $15-$ $19 \%$ of an administered dose of tramadol is excreted in the urine as un-metabolized [7]. Tramadol has been reported by Raffa et al., 1992 [3] to have opioid like effect, hence has some characteristic resemblance as most of the opioid side effects.

The effects of opioid compounds on endocrine function are now fairly well understood and have been termed opioid endocrinopathy. Various studies have demonstrated opioid effects on a variety of hormones including but not limited to testosterone (both total and free) [8, 9], luteinizing hormone (LH) [8, 10], gonadotrophin releasing hormone $(\mathrm{GnRH})[11,12]$ and cortisol [13]. The majority of work has focused on the androgen hormones because of their linkage to many symptomatic side effects of opioid usage. It was found that unlike morphine, tramadol is unlikely to induce tolerance and physical dependence [14]. Other animal studies reported that tramadol did not precipitate or suppress physical withdrawal symptoms in morphinedependent rats, mice and rhesus monkeys $[15,16]$. The shortage of information on the implication of prolonged oral tramadol administration on the reproductive endocrine function of animal motivated this study. Therefore, the work was designed to investigate the effect of prolong use of tramadol as an analgesic on the endocrine function of the male rats. 


\section{MATERIALS AND METHODS}

\section{Experimental Animals and Their Management}

Fifteen sexually matured male albino rat (wistar strain) weighing between $150 \mathrm{~g}-200 \mathrm{~g}$ were selected from Animal House at Physiology Department, University of Ibadan, Oyo state, Nigeria and housed at the experimental animal unit of Faculty of Veterinary Medicine, University of Ibadan, Oyo state, Nigeria. The rats were fed ad libitum with commercially prepared feed (containing 18\% crude protein, $6 \%$ crude fibre, $2750 \mathrm{k} / \mathrm{cal}$ metabolizable energy) and clean water was given ad libitum.

\section{Experimental Drugs}

Tramadol capsules (Ultram®) made in India were purchased from a reputable Pharmacy in Ibadan, Nigeria.

\section{Experimental Design}

Fifteen sexually mature male albino rats (Wistar strains) were used for the study. The rats were divided into two experimental groups (B and C) and control group A comprising five male rats per group. The experimental groups $\mathrm{B}$ and $\mathrm{C}$ were treated orally with $50 \mathrm{mg} / \mathrm{kg}$ and $100 \mathrm{mg} / \mathrm{kg}$ of tramadol respectively while the control group A was given distilled water for 28 days.

\section{Blood Collection}

Blood was collected through the medial canthus of the rat into the plain sample bottles to harvest the serum for hormone analysis.

\section{Serum Hormone Assay}

Serum hormone was assayed from blood obtained from left ventricular puncture. The samples were assayed in batches from a standardized curve using the enzyme linked immunosorbent assay (ELISA) method [17]. The microwell kits used were from Syntro Bioresearch Inc., California USA. Using $10 \mu \mathrm{l}$ of the standard, the samples and control were dispensed into coated wells. $100 \mu \mathrm{l}$ of each hormone conjugate reagent was added followed by $50 \mu \mathrm{l}$ of anti-hormone reagent. The contents of the microwell were thoroughly mixed and then incubated for $90 \mathrm{~min}$ at room temperature. The mixture was washed in distilled water and further incubated for $20 \mathrm{~min}$. The reaction was stopped with $100 \mu \mathrm{l}$ of $1 \mathrm{~N}$ hydrochloric acid. Absorbance was measured with an automatic spectrophotometer at 450 nm. A standard curve was obtained by plotting the concentration of the standard against the absorbance and hormones concentration was determined from the standard curve.

\section{Statistical Analysis}

Data obtained from this study was analyzed using the statistical package of social science (SSPS) version 17.0 for windows. Analysis of variance (ANOVA) was done at 0.05 level of significance which $p<0.05$ was said to be statistically significant. The result obtain was represented as means \pm S.E.M.

\section{RESULT}

The mean serum testosterone concentration of groups B $(50 \mathrm{mg} / \mathrm{kg})$ and C $(100 \mathrm{mg} / \mathrm{kg})$ were, $3.2 \pm 0.04$ and $2.6 \pm 0.05 \mathrm{ng} / \mathrm{ml}$ respectively and these values were significantly lower $(p<0.05)$ than the value of the control (5.2 \pm 0.10$)$. The mean serum Luteinizing Hormone concentration of control group, groups B $(50 \mathrm{mg} / \mathrm{kg})$ and $\mathrm{C}(100 \mathrm{mg} / \mathrm{kg})$ were $3.20 \pm 0.5 \mathrm{ng} / \mathrm{mL}$, $2.1 \pm 0.41 \mathrm{ng} / \mathrm{mL}$ and $1.28 \pm 0.39 \mathrm{ng} / \mathrm{mL}$ respectively. Comparing group B and group $\mathrm{C}$ with the control, significant reductions $(p<0.05)$ were observed. The same trend was observed with serum Follicle Stimulating Hormone where control group had significantly higher value $(3.70 \pm 4.57 \mathrm{ng} / \mathrm{mL})$ at $\mathrm{p}<0.05$, when compared with groups B $(2.66 \pm 2.46 \mathrm{ng} / \mathrm{mL})$ and C $(1.18 \pm 0.86 \mathrm{ng} / \mathrm{mL})$. The mean serum prolactin of 50 and $100 \mathrm{mg} / \mathrm{kg}$ treatment groups were, $2.26 \pm 0.53$ and $4.12 \pm 0.73 \mathrm{ng} / \mathrm{mL}$ respectively. Both values were significantly higher than the value obtained for the control group $(1.60 \pm 4.17)(\mathrm{p}<0.05)$.

Table-1: The hormone profile of male albino rat (wistar strain) exposed to long term tramadol treatment

\begin{tabular}{|l|l|l|l|l|}
\hline Parameter & $\begin{array}{l}\text { Luteinizing } \\
\text { hormone }(\mathbf{n g} / \mathbf{m l})\end{array}$ & $\begin{array}{l}\text { Follicle stimulating } \\
\text { hormone (ng/ml) }\end{array}$ & $\begin{array}{l}\text { Prolactin } \\
(\mathbf{n g} / \mathbf{m l})\end{array}$ & $\begin{array}{l}\text { Testosterone } \\
(\mathbf{n g} / \mathbf{m l})\end{array}$ \\
\hline Control Group A & $3.20 \pm 0.55^{\mathrm{a}}$ & $3.70 \pm 4.57^{\mathrm{ab}}$ & $1.60 \pm 4.17^{\mathrm{a}}{ }^{\mathrm{b}}$ & $5.2 \pm 0.10^{\mathrm{a}}$ \\
\hline Group B (50mg/kg) & $2.14 \pm .41^{\mathrm{a}}$ & $2.66 \pm 2.82^{\mathrm{a}}$ & $2.26 \pm 0.75^{\mathrm{a}}$ & $3.2 \pm 0.04^{\mathrm{a}}$ \\
\hline Group C (100mg/kg) & $1.28 \pm 0.39^{\mathrm{b}}$ & $1.18 \pm 0.86^{\mathrm{b}}$ & $4.12 \pm 0.73^{\mathrm{b}}$ & $2.6 \pm 0.05^{\mathrm{b}}$ \\
\hline
\end{tabular}

Values with the same superscript in the same column are significantly different $(\mathrm{p}<0.05)$

\section{DisCUSSION}

The consequence of chronic drug therapy resulting into sexual dysfunction has been reported with a wide range of drug. Chowdhuru 1987 [18] reported that about $15 \%$ of the 200 most commonly prescribed drugs such as sedatives, tranquillizers, hypnotics, narcotics and cannabis can have adverse effect on male reproduction. The reproductive adverse effect of antihypertensive, antipsychotics and antidepressants drug has also been reported by Maclean and Lee [19]. Several chronic uses of opiates has also been reported to decrease the level of sex hormones in both sexes resulting into diminished fertility of both male and female opiate users. This present study investigating endocrine function upon prolonged treatment with 
$50 \mathrm{mg} / \mathrm{kg}$ and $100 \mathrm{mg} / \mathrm{kg}$ body weight of tramadol revealed deleterious effects of the drug on some sex hormone production of male rats. Several studies concerned with the gonadal activity during drug therapy corroborates with the present results. The decrease in serum level of LH, FSH and testosterone with an increase in prolactin secretion after morphine and methadone administration has been reported by Chowdhury [18] and Bowman and Rand [20] reported an increase in prolactin after sertraline administration. Another independent investigation reported a reduction in serum level of LH, FSH and testosterone and the induction of prolactin secretion after prolonged paroxetine treatment [21]. The reduction in serum level of FSH, LH and testosterone with an increase in treatment dosage may signify that the drug on long term use cause gonadal degeneration leading to low production of the gonadotropins which may ultimately lead to low libido and infertility. Also the observed decrease in FSH, LH and testosterone which is dose dependence reflects lack of steroid negative feedback mechanism and failure of the hypothalamo-pituitarygonadal axis due to the prolonged usage of the drug [22]. In conclusion, the prolonged use of the tramadol at $50 \mathrm{mg} / \mathrm{kg}$ and $100 \mathrm{mg} / \mathrm{kg}$ in the albino rat revealed malfunctioning of the reproductive endocrine thereby resulting into hormonal imbalance which may lead to infertility in the male rat. Therefore prolonged used of tramadol should be cautiously monitored in animal meant for breeding purpose.

\section{REFERENCES}

1. Grünthal G. Spectral response of soil conditions to seismic motions-studies for detailed dynamic soil characteristics. InSymposium on the Analysis of Seismicity and on Seismic Risk (Liblice, Czechoslovakia 1978) 1978.

2. McMillian, J. C., \& Buhle, P. (2008). The new left revisited. Temple University Press.

3. Raffa RB, Friderichs E, Reimann W, Shank RP, Codd EE, Vaught JL. Opioid and non-opioid components independently contribute to the mechanism of action of tramadol, an 'atypical' opioid. Journal of Pharmacology Experimental and Therapeutics. 1992; 260:275-285.

4. Matthiesen J, inventor. Flask. United States patent application US 29/036,462. 1997 Aug 5.

5. KuKanich B, Papich MG. Pharmacokinetics of tramadol and the metabolite O-desmethyltramadol in dogs. Journal of Veterinary Pharmacology and Therapeutic. 2004; 27: 239-246.

6. Lintz W, Erlac S, Frankus E, Uragg $H$. Biotransformation of tramadol in man and animals. Arzneim Forsch Drug Res. 1981; 31, 1932-1943.

7. Lintz, W., Barth, H., Osterloh, G., \& Schmidt-Böthelt, E. (1998). Pharmacokinetics of tramadol and bioavailability of enteral tramadol formulations. 3rd Communication:

Forschung, 48(9), 889-899.

8. Daniel HW. Opioid endocrinopathy in women consuming prescribed sustained- action opioids for control of non-malignant pain. Journal of Pain Management. 2008; 9:28-36.

9. Bliesener N, Albrecht S, Schwager A, Weckbecker K, Lichtermann D, Klingmuller D. Plasma testosterone and sexual function in men receiving buprenorphine maintenance for opioid dependence. The Journal of Clinical Endocrinology \& Metabolism. 2005 Jan 1;90(1):203-6.

10. Abs, R, Verhelst J, Maeyaert J, Van Buyten JP, Opsomer F, Adriaensen H, Verlooy J, Van Havenbergh T, Smeth M, Van Acker K. Endocrine consequences of long-term intra-thecal administration of opioids. Journal of Clinical Endocrinology and Metabolism. 2000; 85:2215-2222.

11. Delitala G, Grossman A, Besser M. Differential effects of opiate peptides and alkaloids on anterior pituitary hormone secretion. Neuroendocrinology. 1983;37(4):275-9.

12. Brown KB, Allegretto W, Vermuelen FE, Lawson RP, Robinson AM. Cantilever-in-cantilever micromachined pressure sensors fabricated in CMOS technology. InEngineering Solutions for the Next Millennium. 1999 IEEE Canadian Conference on Electrical and Computer Engineering (Cat. No. 99TH8411) 1999 May 9 (Vol. 3, pp. 1686-1691). IEEE.

13. Oltmanns U, Chung KF, Walters M, John M, Mitchell JA. Cigarette smoke induces IL-8, but inhibits eotaxin and RANTES release from airway smooth muscle. Respiratory research. 2005 Dec;6(1):1-0.

14. Hayek FA. Law, legislation and liberty, volume 1: Rules and order. University of Chicago Press; 1978 Feb 15.

15. Goeringer KE, Logan BK, Christian GD. Identification of tramadol and its metabolites in blood from drugrelated deaths and drug-impaired drivers. Journal of analytical toxicology. 1997 Nov 1;21(7):529-37.

16. Spiller HA, Gorman SE, Villalobos D, Benson BE, Ruskosky DR, Stancavage MM, Anderson DL. Prospective multicenter evaluation of tramadol exposure. Journal of Toxicology: Clinical Toxicology. 1997 Jan 1;35(4):361-4.

17. Tietz HJ, Küssner A, Thanos M, De Andrade MP, Presber W, Schönian G. Phenotypic and genotypic characterization of unusual vaginal isolates of Candida albicans from Africa. Journal of clinical microbiology. 1995 Sep 1;33(9):2462-5.

18. Chowdhury BA, Chandra RK. Biological and health implications of toxic heavy metal and essential trace element interactions. Progress in food \& nutrition science. 1987;11(1):55.

19. Maclean F, Lee A. (13) Drug-Induced Sexual Dysfunction and Infertility. Pharmaceutical journal. 1999;262(7047):780-4.

20. Bowman WC, Rand MJ. The reproductive system and drugs affecting the reproductive systems. Textbook of pharmacology, 2ed, 2000; 20:1-8.

21. EL-Gaafarawi I, Hassan M, Fouad G, El-Komey F. Toxic effects of paroxetine on sexual and reproductive functions of rats. The Egyptian Journal of Hospital Medicine. 2005 Oct 1;21(1):16-32.

22. Melmed S. Update in pituitary disease. The Journal of Clinical Endocrinology \& Metabolism. 2008 Feb 1;93(2):331-8. 